\title{
A NEW LEGAL ORDER, OR A NON-EXISTENT ONE? SOME (EARLY) EXPERIENCES IN THE APPLICATION OF EU LAW IN CENTRAL EUROPE
}

\begin{abstract}
Michal Bobek*
Summary: One of the mantras of European Community Law is that which defines it as "[...] a new legal order of international law [...]". ${ }^{1}$ Like every mantra, this one has become a quasi-compulsory quote at the opening of every other treatise on EC law. If we take the Van Gend statement as our starting point, how is the "new legal order" doing in the new Member States, some two years after accession?

This paper consists of three parts. The first part discusses current "European" case law in national courts, giving examples of the use of EC law before domestic courts. Special attention is paid to cases which "made it to Luxembourg", i.e. references for preliminary rulings from the new Community courts. The second part of the paper focuses on three particular areas that are currently of great importance to the smooth application of EC law in the new Member States: issues concerning the temporal application of EC law and inter-temporal arrangement; the problem of the lack of due publication of EC law provisions in the languages of the new Member States; and the question of who is supposed to be acquainted with, and raise points about, Community law before a court. The third part of the paper makes some generalisations about the current and future application of EC law in Central Europe.

The focus of this paper is limited: our area of territorial analysis will be the "Visegrad states", i.e. the Czech Republic, the Slovak Republic, Poland and Hungary. ${ }^{2}$ of these four, the greatest attention will be paid to the current situation in the Czech Republic.
\end{abstract}

\section{EC law in national courts - cases}

Current case law, most of which is still pending, is extremely diverse. It can hardly be put into any neat scientific boxes. For the sake of accessibility, let us divide it into three categories:

\footnotetext{
"Law clerk (référendaire) to the Chief Justice, Supreme Administrative Court of the Czech Republic, Brno. I owe my thanks to Jan Komárek, Mark Gillis and Zdeněk Kühn for their valuable comments and suggestions. This article reflects the law as it stood in March 2006. Contact: michal.bobek@st-edmund-hall.oxon.org

${ }^{1}$ Case 26/62 NV. Algemene Transport- en Expeditie Onderneming van Gend \& Loos v. Netherlands Inland Revenue Administration [1962] ECR 1, at page 5.

2 The Visegrad Group, comprising these four states, is named after a castle and town in Hungary where the group was formed on 15 February 1991.
} 
(i) cases in which EC law points were raised and the case was sent for preliminary ruling to the Court of Justice;

(ii) cases in which EC law was, or most likely will be, directly applied, where the EC law angle is decisive for the dispute;

(iii) cases in which EC law was, or is likely to be, discussed as a subsidiary argument.

\section{I.1. Preliminary rulings - the "long-awaited party" phenomenon}

At the time of writing of this article (March 2006), there were nine requests for preliminary ruling from the Visegrad states (which, as it happens, account for the totality of such requests from all the new Member States. ${ }^{3}$ Six of these were still pending before the Court, while three had already been decided. Five of the nine requests came from Hungary, ${ }^{4}$ one from Poland, ${ }^{5}$ and three from the Czech Republic. ${ }^{6}$

The first two cases, which were already submitted in the summer of 2004, both came from Hungary. The Court of Justice decided them in October 2005 and January 2006, respectively. Case C-328/04, Attila Vajnai, demonstrates that asking the first question is not all that important. What matters more is to ask a meaningful one.

Attila Vajnai concerned the criminal conviction of Mr Vajnai, vicepresident of the Hungarian Worker's Party. In February 2003 Mr Vajnai took part in a demonstration in Budapest. In the course of the demonstration, he pinned a red star about 5 centimetres in size to his clothing, and drew the attention of the crowd and the press to it. Due to this he was prosecuted and found guilty of the minor offence of using a totalitar-

\footnotetext{
${ }^{3}$ There would seem to be another reference for preliminary ruling from the Supreme Administrative Court of Lithuania, made by a judgment of that court of 20 December 2005 in case A15-1292-2005, concerning the excise duty on alcoholic beverages. This case has not yet been assigned a case number in the Court of Justice's registry, and there has been no notice in the Official Journal.

${ }^{4}$ Case C-302/04 Ynos kft v János Varga [2006] ECR I-00371; case C-328/04 Criminal proceedings against Attila Vajnai,[2005] ECR I-08577; case C-261/05 Lakél Kft.,Pár-Bau Kft., and Rottelma Kft. v Komárom-Esztergom Megvei Közigazgatási Hivatal [2005] OJ C 205/13; case C-290/05 Ákos Nádasdi v Vám-és Pénzügyörség Észak-Alföldi Regionális Parancsnoksága [2005] OJ C 296/10; case C-333/05 Ilona Németh v Vám-és Pénzügyörség Dél-Alföldi Regionális Parancsnoksága [2005] OJ C 315/8.

${ }^{5}$ Case C-313/05, Maciej Brzeziński v Dyrektor Izby Celnej $w$ Warszawie [2005] OJ C $281 / 5$.

${ }^{6}$ Case C-437/05 Jan Vorel v Český Krumlov Hospital and case C-64/06, Český Telecom, a.s. v. Czech On Line, a.s. (notice not yet published in the OJ). A third request for preliminary ruling originating from Czech courts has not yet been assigned a case number in the Court of Justice's registry; it concerns the enforceability of customs regulations which were not duly published, and was made by an order of the Regional Court in Ostrava of 10 February 2006, case 22 Ca 69/2005-43 Skoma-Lux, s.r.o. v. Celní ředitelstuí Olomouc. It is discussed below in section II.2.
} 
ian symbol in public, which is prohibited by Art. 269/B, paragraph 1(b) of the Hungarian Criminal Code. Under that provision, a person who makes public use of the swastika, the SS insignia, the "arrow cross", the hammer and sickle, the five-pointed red star, or any other sign representing one of these symbols has committed a minor offence punishable by a fine - provided that such conduct does not lead to a more serious criminal offence.

The Budapest Metropolitan Court (Fövárosi Bíróság), considering this case on appeal, decided to stay the proceedings and ask the Court of Justice whether the Hungarian ban on symbols of totalitarianism was compatible with Art. 6 of the Treaty on the European Union and Community law principles of non-discrimination, freedom of expression and political conviction. The argument put forward by the Metropolitan Court was rather obscure: the court indicated that in Italy, for instance, members of left-wing parties are allowed to use such symbols as the red star or the hammer and sickle. Prohibiting the same conduct in Hungary constitutes discrimination and disregards principles common to all Member States.

By an order dated 6 October 2005, the Court of Justice rejected the request as manifestly inadmissible. In paragraphs 13 and 14 of the order, the Court held that it has no competence to reply to questions outside the framework of Community law, with no connection whatsoever to any of the Treaty's provisions. ${ }^{7}$

The second request for preliminary ruling from the new Member States, decided by the Court of Justice on 10 January $2006,{ }^{8}$ was slightly more successful than its predecessor. This time around the Court made its decision in the form of a judgment. However, in four short paragraphs representing its entire legal reasoning, the Court held that, because the facts of the case in the main proceedings were anterior to Hungary's accession to the European Union, it was not competent to decide on the substance of the issue. ${ }^{9}$

In remaining extremely brief, the Court was more clement towards the Hungarian court than Advocate General Tizzano, who suggested that the Court reject the preliminary reference as partly hypothetical and partly unnecessary for deciding the legal issues in the main proceedings

\footnotetext{
7 The Court of Justice draws a parallel with the first Austrian request for preliminary ruling, which could not be described as a success, either: case C-299/95 Friedrich Kremzow v Republik Österreich [1997] ECR I-2629.

8 Case C-302/04 Ynos kft v János Varga, [2006] ECR I-00371

${ }^{9}$ What this decision means for the temporal application of Community law in the new Member States is discussed below in section II. 1. Applying the rationale in Ynos, the Court of Justice rejected the third Hungarian reference (case C-261/05 Lakél Kft.) by a reasoned order of 9 February 2006.
} 
before the domestic court. ${ }^{10}$ It may be said that the AG's analysis is persuasive in many respects; the question submitted to the Court, concerning abusive clauses in commercial contracts, seems somehow artificial.

The first Polish request for a preliminary ruling ${ }^{11}$ marked a refreshing change in this wave of rather dubious preliminary references. It is perhaps not surprising that the first question from Poland was an attack on the Polish excise duty levied on second-hand cars imported to Poland from other Member States, an area of activity in which some Polish businesspeople seem to be quite successful. The request contains complex reasoning, arguing that by levying an excise duty on all imported second-hand cars from other Member States, but not on second-hand cars already registered and resold in Poland, Articles 23, 25 and 90 TEC have been infringed.

Similar issues were raised in two recent Hungarian references. ${ }^{12}$ Both cases challenge the Hungarian law on the registration duty for second-hand cars. When a used car is purchased in another Member State, a person wishing to place the vehicle in circulation in Hungary (to enter it in the national registry of cars and have a licence issued) must pay a registration fee. The same fees must be paid on Hungarian cars when they are first placed on the market; these normally form part of the car's selling price. If, however, the car was originally sold first in another Member State, and then imported into Hungary as a second-hand car, the registration fee has already been paid in the car's state of origin. The question raised by the Hungarian courts is whether or not levying a registration fee for a second time in another Member State represents a breach of the first paragraph of Art. 90 TEC (discriminatory taxation).

The first Czech request for a preliminary ruling, case C-437/05, Vorel, concerns payment for on-call duty by a hospital surgeon. All medical staff are required to serve a certain amount of on-call duty in emergency medical services. For most of this time, the staff may not actually be working, but only waiting in "stand-by mode" for an emergency call. They must, however, be present at their workplace. The question which arose was how such "stand-by" work is to be remunerated: at the full rate, or at a reduced rate? ${ }^{13}$

${ }^{10}$ Cf. paras 52 - 70 of the Opinion of AG Tizzano of 22 September 2005 in case C-302/04 Ynos Kft. (n 8).

11 Case C-313/05 Brzeziński (n 5).

12 Case C-290/05 Nádasdi [2005] OJ C 296/10 and case C- 333/05 Németh [2005] OJ C 315/8 (n 4).

${ }^{13}$ The reference is, unfortunately, poorly written, so that the real question must be inferred from the other documents submitted to the Court of Justice. This may not be fatal, as the Court could deduce, even from an improperly worded reference, the genuine issue at stake (cf. e.g. case 14/86 Pretore di Salo $v$ Persons unknown [1987] ECR 2545 para 16). The same 
What conclusions (if any) can be drawn from this handful of cases? Some courts might perhaps be too eager to be seen as pro-European, engaging in the European "judicial dialogue" at all costs, without having much to say. Others may be too strongly influenced by the attorneys arguing cases before them. For an attorney, especially one representing the party with poorer chances of success, a request for a preliminary ruling and the consequent temporal transfer of the case to Luxembourg offers an ideal delay and fee-augmenting tactic. ${ }^{14}$ Another, somewhat psychological aspect in the case of some judges and lawyers might be the distinction of being the "first" from their Member State to submit a question to Luxembourg. Even a very remote Community law connection is thus viewed as sufficient for staying the proceedings and submitting a question to the Court of Justice. As with the other motives, this one also does not guarantee the meaningfulness of the question submitted.

For perhaps similar reasons, a growing number of cases with obscure EC law points are being raised, together with requests for preliminary ruling sent to Luxembourg. One such example: in a series of restitution cases, ${ }^{15}$ the Supreme Court of the Czech Republic rejected the repeated requests for preliminary ruling made by an unsuccessful claimant, a member of the pre-WWII Czech aristocracy, who argued that the Czech courts deciding his restitution cases were biased and under political pressure. He suggested that a request for preliminary ruling be submitted regarding the interpretation of Art. 6 (1) TEU, i.e. whether it was possible, in a particular case where political interference with the independence of the courts has compromised their impartiality and independence, to transfer the case to courts in other Member States. These requests were rejected

issue has, however, already been addressed by the Court of Justice in case C-14/04 Abdelkader Dellas and Others $v$ Premier ministre and Ministre des Affaires sociales, du Travail et de la Solidarité [2005] ECR I-10253, and in previous case law (cf. e.g., case C-241/99 Confederación Intersindical Galega (CIG) v Servicio Galego de Saúde (Sergas) [2001] ECR I5139). It is, therefore, likely that the Court of Justice may reply with a reasoned order under art 104 (3) of the Rules of Procedure.

${ }^{14}$ A typical case of this type is currently pending before the Municipal Court in Prague (Administrative Division). It is the case 7 Ca 193/2005. It concerns the granting of a bus line licence pursuant to Council Regulation (EC) no. 11/98 of 11 December 1997, amending Regulation (EEC) no. 684/92, on common rules for the international carriage of passengers by coach and bus, [1998] OJ L 4/1. The applicant, an international bus company, criticises the decision by the Ministry of Transportation to allow another company to provide services on the same line as that already granted to the applicant. The applicant has requested, in the action itself, suspension of the Ministry's decision and referral of the case for preliminary reference to Luxembourg. The motivation of the request is obvious; should the Ministry's decision be suspended and the case sent to Luxembourg, the applicant could forestall any unwelcome competition for the next two years.

15 Order of the Supreme Court of 28 April 2005, case 28 Cdo 810/2005; order of the Supreme Court of 3 August 2005, case 28 Cdo 1347/2005; order of the Supreme Court of 23 November 2005, case 28 Cdo 2420/2005; all decisions available at http://www.nsoud.cz. 
by the Supreme Court as manifestly unfounded. Similar attempts have also been rejected by the Slovak Constitutional Court in a case concerning jurisdictional issues under Regulation $44 / 2001,{ }^{16}$ and by some other lower courts in the region. ${ }^{17}$

It is vital that new Community judges, in similar types of cases, realise that submitting a request for preliminary ruling to Luxembourg is a right, not an obligation. Apart from the obligation, in certain cases pertaining to courts of last instance, to submit a preliminary reference to the Court of Justice, ${ }^{18}$ it is for the national court, which knows the facts of the case and the arguments of the parties, to assess the need for a preliminary ruling in the given dispute. ${ }^{19}$ A national judge should not succumb to the temptation of having a case sent to, and resolved in, Luxembourg; the possibility of consulting the Court of Justice does not relieve a national judge of his duty to apply Community law independently.

\section{I.2. EC law in national courts only}

As already mentioned above, any systematisation of EC law issues currently pending or recently decided before the new Community courts borders on the impossible. A very rough division might be made according to the strength of the EC law argument in the dispute. There are already quite a few cases in which EC law is being used as a source of subsidiary legal arguments, i.e. a reference to EC law confirms the result reached by applying national legal provisions. These cases typically involve some sort of indirect effect, especially in the area of implementing EC directives.

Cases in which EC law constitutes the focal legal argument are rare. These mostly involve direct application of a source of Community law (regulations, Treaty provisions). However, before we analyse cases in the first or second category, let us first briefly consider some "heavyweight" constitutional cases.

\footnotetext{
${ }^{16}$ Order of the Constitutional Court of the Slovak Republic of 30 March 2005, case II. US 90/05-26, available at http://www.concourt.sk.

${ }^{17}$ Cf. e.g. the judgment of the Regional Court in Ustí nad Labem (pobočka Liberec) of 30 September 2004 in Kinski v. MTT Company, case 35 Co 213/2004-137, unpublished.

18 Case 283/81 Srl CILFIT and Lanificio di Gavardo SpA v Ministry of Health [1982] ECR 3415. For more, see M Bobek, Porušení povinnosti zahájit řizení o předběžné otázce podle článku 234 (3) SES. [Violation of the Duty to Make a Preliminary Reference under Article 234 (3) TEC] (CH Beck, Prague 2004) 32 et seq.

${ }^{19}$ Cf. case 83/78 Pigs Marketing Board v Raymond Redmond [1978] ECR 2347 para 25 or case C-320/94 Reti Televisive Italiane SpA (RTI) v Ministero delle Poste e Telecomunicazioni [1996] ECR I-6471 para 21.
} 


\section{I.2.1. The "big ones"}

There seems to be a strange kind of inverse proportion between the amount of EC "constitutional cases" in the new Member States and the paper (or electronic pages) devoted to discussing them. European Arrest Warrant decisions seem to take centre stage, ${ }^{20}$ followed by classic primacy-related cases ${ }^{21}$ and Constitutional and Accession Treaty disputes. ${ }^{22}$ These cases will not be discussed in this paper. First of all, reference can be made to more elucidating comments on this subject. ${ }^{23}$ Also, despite their political "weight", cases of this type are marginal in terms of day-to-day application and effective enforcement of EU law in the new Member States. Such cases come up once or twice in a decade, and they are always unique. They are dealt with exclusively at the supreme or constitutional level of the national adjudicative machinery. To put this more plainly, the overall majority of, say, Polish citizens are not concerned with the validity of the European Arrest Warrant and ideas about European constitutional pluralism, intriguing as these may be; rather, they are interested in whether or not the excise duty on any car imported from other Member States violates the ban on discriminatory taxation under Art. 90 ECT. ${ }^{24}$

${ }^{20}$ Cf. e.g. the decision of the Polish Constitutional Tribunal of 27 April 2005, case P 1/05, available at http://www.trybunal.gov.pl; the decision of the Supreme Court of the Republic of Cyprus of 7 November 2005, case 294/2005; and also the decision of the Federal German Constitutional Court of 18 July 2005, case 2 BvR 2236/04, available at http://www.bverfg. de. The question concerning the validity of the European Arrest Warrant is now pending before the Court of Justice on a preliminary reference made by the Belgian Cour d'Arbitrage in case C-303/05 Advocaten voor de Wereld, [2005] OJ C 271/14. The question is also pending before the Czech Constitutional Court in case Pl. ÚS 66/04, submitted by a group of senators and deputies of the Czech Parliament.

${ }^{21}$ Cf. the decision of the Polish Constitutional Tribunal of 11 May 2005, case K 18/04, at http://www.trybunal.gov.pl.

${ }^{22}$ Cf. e.g. the pending challenge before the Slovak Constitutional Court to Slovak Act of Parliament no. 1596 of 11 May 2005, whereby Parliament approved ratification of the Treaty on the Constitution for Europe. A constitutional complaint was filed on 8 June 2005 by the Christian Democrats and the Conservative Party. They argue that the Act of the Parliament was unconstitutional, as Parliament was bound to hold a referendum on the Constitution for Europe.

${ }^{23}$ See e.g. K Kowalik-Bańczyk, 'Should We Polish It Up? The Polish Constitutional Tribunal and the Idea of Supremacy of EU Law'.(2005) 6 German Law Journal 1355, available at http://www.germanlawjournal.org; J Komárek, 'Pluralismo constitucional europeo tras la ampliación. Un análisis de la jurisprudencia comunitaria del Tribunal Constitucional polaco' (2005) 16 Revista española de Derecho Europeo; J Weigend, T Górski, 'Die Implementierung des Europäischen Haftbefehls in das polnische Strafrecht' (2005) 117 Zeitschrift für die gesamte Strafrechtswissenschaft 193, pp 196-197; A Łazowski, 'Constitutional Tribunal on the Surrender of Polish Citizens under the European Arrest Warrant. Decision of 27 April 2005' (2005) 1 European Constitutional Law Review 569.

${ }^{24}$ Case C-313/05, Brzeziński, see n.5. 
There is, however, one constitutional law case which stands out from the crowd of accession and EAW case law. This is the Slovak Constitutional Court's decision of 18 October $2005^{25}$ concerning Slovak implementation of Council Directive 2000/43/EC of 29 June 2000 on the principle of equal treatment of persons irrespective of racial or ethnic origin. ${ }^{26}$ Art. 5 of the Directive allows for positive action by "[...] maintaining or adopting specific measures to prevent or compensate for disadvantages linked to racial or ethnic origin." This provision was transposed almost verbatim into Art. 8, para. 8 of Slovakia's Act implementing the Directive, ${ }^{27}$ having been inserted into the original government proposal by the Slovak Parliament (National Council). The government then challenged the Act before the Constitutional Court, arguing that the inserted positive action provision was in violation of Art. 12 (equality) and Art. 1 (rule of law) of the Slovak Constitution. The Court allowed the complaint and annulled the contested Art. 8, para. 8 of the Act.

The decision itself addressed points of EC law only marginally. ${ }^{28}$ More interesting is the forerunner to the decision on the merits of the case, i.e. the Court's order of 18 May 2005, ${ }^{29}$ whereby the Constitutional Court rejected the Slovak Parliament's motion for preliminary reference to the Court of Justice. The Constitutional Court considered itself to be a "court or tribunal" within the meaning of Art. 234 TEC. ${ }^{30}$ It did not, however, consider a request for preliminary ruling to be necessary in order to decide the case in question. ${ }^{31}$ The Slovak Constitutional Court thus actively

${ }_{25}$ Plenary decision of the Constitutional Court of 18 October 2005, case Pl. ÚS 8/04-202, n.y.p., available at http://www.concourt.sk.

${ }^{26}$ OJ [2000] L 180/22.

${ }^{27}$ Zákon č. 365/2004 Z.z. o rovnakom zaobchádzaní v. niektorých oblastiach a o ochrane pred diskrimináciou a o zmene a doplnení niektorých zákonov (antidiskrimina ný zákon).

${ }^{28}$ Citing in para 18 of the decision, the Court's case law in case C-222/84 Marguerite Johnston v. Chief Constable of the Royal Ulster Constabulary [1986] ECR 1651 and case C-285/98 Tanja Kreil v Bundesrepublik Deutschland [2000] ECR I-69, wherein the Court inferred that any provisions derogating from the principle of equality by the use of positive action must be interpreted strictly.

${ }^{29}$ Case no. PL ÚS 8/04-196, available at http:// www.concourt.sk.

${ }^{30}$ This reading of the decision was confirmed by the Chief Justice of the Constitutional Court, Mr. Jan Mazák, writing extra-judicially in: J Mazák, 'The Constitutional Court of the Slovak Republic and its Contribution to the Enforcement of Rights and Obligations Created at the Community Level'. In: '1 Jahr EU Mitgliedschaft: Erste Bilanz aus der Sicht der Slowakischen Höchstgerichte’, (Eif Working Paper Series, Working Paper Nr. 18, Österreichische Akademie der Wissenschaften, Wien 2005) 3, and also in J Mazák, 'Príspevok Ústavného súdu Slovenskej republiky pri uplatńování práv. a plnení povinností na komunitárnej úrovni' (2005) 6 EMP Jurisprudence 11-14.

${ }^{31}$ In which the Court dodged rather than really resolved the question. It may reasonably be argued that there was a strong EC law issue at stake, namely, the proper construction of art 5 of the Directive, or questions concerning the validity thereof. What the Constitutional Court did was not to challenge the Directive directly (for which it would have had to submit 
entered the debate about whether or not constitutional courts are courts within the meaning of Art. 234 TEC, and thus can (and should) submit requests for preliminary ruling to Luxembourg. The Czech Constitutional Court recently adopted a similar view: in its seminal decision on the effect of EC law in the Czech Republic, ${ }^{32}$ the Court observed that it could be a court or tribunal in the meaning of Art. 234 TEC. The Court decided, however, that there was no need, in the case in question, to submit a request for preliminary ruling to Luxembourg. ${ }^{33}$

\section{I.2.2. EC (EU) law as the decisive legal argument}

There are only a handful of cases in which an EC law argument seems to be the decisive one. Two scenarios may be considered here:

(1) EC legislation covers the area of law in question exclusively, while the use of national law is only subsidiary, i.e. national law covers only procedure or sanctions, but there is no conflict of substantive rules (typically, in areas like competition law, customs, or agriculture).

(2)There is a conflict between EC regulations and national legal provisions, which is to be resolved based on the primacy of EC law over conflicting national provisions.

Examples from the first category do not require any detailed explanation. Where there are no national regulations in the given area, and judges are called on to interpret and apply EC law directly, there are usually no problems, apart from questions related to language accessibility and knowledge, which will be dealt with below.

a request for preliminary ruling concerning its validity to Luxembourg), but rather to annul its domestic implementation.

${ }^{32}$ Decision (full court) of the Czech Constitutional Court of 8 March 2006 in case Pl.ÚS 50/04 (the "Sugar Quota" case), not yet published. Of similar importance is the order (full court) of 21 February 2006 in case Pl.ÚS 19/04, in which the Constitutional Court held that courts of general jurisdiction must deal with EC law issues directly or in cooperation with the Court of Justice, and not on the basis of a reference (constitutional reference) to the Constitutional Court.

${ }^{33}$ The forerunner to this debate is the German Federal Constitutional Court (Bundesverfassungsgericht), which had already held in 1979, in BVerfGE 52, 187 - "Vielleicht"-Beschluß (25.07.1979), that it was a court or tribunal within the meaning of art 234 TEC. However, the Bundesverfassungsgericht never submitted a request for preliminary ruling itself. A different approach was taken by the Austrian Federal Constitutional Court (Bundesverfassungsgerichtshof), which has addressed the Court of Justice on several occasions already (cf. e.g. case C-143/99 Adria-Wien Pipeline GbmH, Wietersdorfer \& Peggauer Zementwerke GmbH v Finanzlandesdirektion für Kärnten [2002] ECR I-8365; case C-465/00 Rechnungshof v Österreichischer Rundfunk E. A. [2003] ECR I-04989; or case C-171/01 Wählergruppe „Gemeinsam Zajedno/Birlikte Alternative und Grüne GewerkschafterInnen/UG“, and Bundesminister für Wirtschaft und Arbeit and Others [2003] ECR I-4301). 
Examples of such direct use of EC law concern diverse areas: competition law, ${ }^{34}$ asylum and migration, ${ }^{35}$ transportation policy, or customs. ${ }^{36}$ One often neglected area of the direct application of EC law is civil cooperation in judicial matters, especially the domestic application of Council Regulation 44/200 $1^{37}$ and Council Regulation 1348/2000. ${ }^{38}$

The potential primacy cases are more intriguing. At the time this paper was written, there had not yet been a single case in which a Czech or other Visegrad state court had explicitly accorded EC law primacy over national law. ${ }^{39}$ There are, however, indications that similar questions will have to be confronted sooner or later. Examples of this type of case law include the national wine tax, a measure whose effect is potentially equivalent to a quantitative restriction on imports, ${ }^{40}$ a challenge before the Constitutional Court to the new Czech Public Healthcare Insurance Act ${ }^{41}$ or the contentious issue of the legality of sanctions for violating the

${ }^{34}$ The area of competition law, especially following the entry into force of Modernisation Regulation 1/2003, is without any doubt the most "Community-friendly" area of municipal law. Both the Czech regulatory agency (Office for the Protection of Competition) and the administrative courts reviewing that agency's decisions commonly work with EC legislation and Court of Justice case law.

35 Judgment of the Městský soud v. Praze (Municipal Court in Prague (Administrative division)) of 20 June 2005, case 7 A $7 / 2005$, unpublished. The case concerned a Slovak woman who had requested the granting of political asylum in the Czech Republic. The Municipal Court dismissed her application without examining the merits of the case, directly applying the Protocol annexed to the Treaty of the European Community - the Protocol on Asylum for Nationals of Member States of the European Union ([1997] OJ C 340/103).

${ }^{36}$ Case 7 Ca 193/2005, pending before the Municipal Court in Prague (Administrative Division). For more, see supra note 15 .

${ }^{37}$ Council Regulation (EC) no. 44/2001 of 22 December 2000 on jurisdiction and the recognition and enforcement of judgments in civil and commercial matters, [2001] OJ L 12/1.

${ }^{38}$ Council Regulation (EC) no. 1348/2000 of 29 May 2000 on the service of judicial and extrajudicial documents in civil or commercial matters in the Member States, [2000] OJ L $160 / 37$.

${ }^{39}$ Or at least the conflict was not directly recognised. It could be argued that, in the previously mentioned case of the Slovak asylum-seeker (see n. 35), the Protocol on Asylum for Nationals of Member States of the European Union took primacy over the Czech Asylum Act. The issue was, however, construed differently: according to the Municipal Court's reasoning, the Protocol was lex specialis to the general Czech Asylum Act (lex generalis). As such, no direct conflict arose, as it could be argued that the special situation of an asylumseeker from Slovakia had not been provided for in Czech law.

${ }^{40}$ Case $30 \mathrm{Ca}$ 131/2005, pending before the Regional Court in Brno, Czech Republic. The case raises some complex issues concerning the Act on Accession as well as the previous Europe Agreements. The applicant, a Czech wine importer, argues that redistribution of the revenues of the National Wine Fund, which are given solely to Czech wine producers, and not to importers of wine from other Member States, is discriminatory and constitutes a measure whose effect is equivalent to a quantitative restriction on imports. If the court were to allow the applicant's claim, it would have to disapply national legislation (an act of Parliament) which is in violation of the Europe Agreement.

${ }^{41}$ Cases Pl 16/2005, Pl. 35/2005 and Pl. 36/2005, all currently pending before the Constitutional Court. 
Common Customs Tariff where this has not been duly published in the official language of the Member State. ${ }^{42}$

The bitter ongoing judicial saga concerning Czechoslovak pensions has a rather uncertain EC law status. The facts of this case reach back to the pre-1993 Czechoslovak Federation. Upon the division of the former Czechoslovakia, one of the separation-related treaties between the successor states provided for social security and pension benefits following separation. The basic rule adopted was that a pension should be paid by the state on whose territory the legal entity a person had worked for was incorporated, or, if the person was self-employed, by the state on whose territory he or she had worked. ${ }^{43}$

With the gradual divergence of economic conditions in the two successor states, pensions paid to people who had worked on the territory of the Czech Republic became considerably higher than those paid to people who had worked in Slovakia. This situation was especially burdensome for some Czech nationals, who had always had Czech citizenship and had worked for Czech companies on the territory of Slovakia. These people, most of whom lived in the Czech Republic after retirement, were only entitled to considerably lower Slovak pensions, despite the fact that they were Czech citizens who had worked for Czech firms.

Following a series of constitutional complaints, ${ }^{44}$ the Czech Constitutional Court decided that Czech citizens working for Czech firms in Slovakia cannot be said to have worked abroad, and that their pension claims should be calculated based on their Czech citizenship. The court held that any other conclusion would violate the constitutional imperative of equality and equal access to social security. All Czech citizens should, therefore, be entitled to the same pensions, irrespective of whether they worked on Czech or Slovak territory prior to the split of the Czechoslovak Federation.

This approach has been rejected by the Czech administrative judiciary thus far. ${ }^{45}$ The main argument of the administrative courts, headed by the Czech Supreme Administrative Court, is that entitlements under social security laws cannot be based on citizenship, but rather on territoriality and a person's actual place of work. In its decisions on this issue,

\footnotetext{
${ }^{42}$ For more, see infra, section II.2.

${ }^{43}$ Art 20 of the Smlouva mezi Českou republikou a Slovenskou republikou o sociálním zabezpečeni [Treaty on Social Security between the Czech Republic and the Slovak Republic], published in the Czech Collection of Laws as no. 228/1993 Coll.

${ }^{44}$ Cf. the decision of 3 June 2003, case II. ÚS 405/02; the decision of 25 January 2005, case III. ÚS 252/04; or the decision of 4 April 2005, case IV. ÚS 158/04, all available at http://www.judikatura.cz.

${ }^{45}$ Cf. the judgment of 19 February 2004, case 3 Ads 2/2003-60, or the judgment of 23 February 2005, case 6 Ads 62/2003-31, available at http://www.nssoud.cz.
} 
the Supreme Administrative Court has referred to Community legislation in this area ${ }^{46}$ which emphasises the notion of residence, not citizenship. It could be argued that the approach chosen by the Constitutional Court is in breach of Community rules, as it establishes de facto discrimination based on nationality. On the other hand, the facts and the legal regime in question date back a time long before Czech and Slovak accession to the European Union, the group of people concerned is a closed one, and the case refers to an extraordinary situation conditioned by the dissolution of a state. The newly-adopted stance of the Court of Justice in Ynos $k \mathrm{ft}^{47}$ would seem to imply that these questions are to be regarded as outside the scope of Community law.

\section{I.2.3. EC law as an interpretive aid}

Instances where EC law is used as an interpretive aid are quite common. The majority of these cases concern the indirect effect of directives. ${ }^{48}$ Directives are used as an interpretive aid to discern the meaning of national legislation adopted in order to transpose these same directives into the national legal order. Cases of this sort may involve the portability of mobile phone numbers, ${ }^{49}$ late payments in commercial transactions, ${ }^{50}$ issues concerning the nature of financial leasing, ${ }^{51}$ or whether or not the Czech Airport Administration Agency is a "public undertaking" for the purposes of administrative judicial review. ${ }^{52}$

\footnotetext{
${ }^{46}$ Council Regulation (EEC) no. 1408/71 of 14 June 1971 on the application of social security schemes to employed persons and their families moving within the Community, [1971] OJ L 149/2, as (frequently) amended.

47 See below, section II. 1 .

48 S Prechal, Directives in EC Law ( $2^{\text {nd }}$ Ed., Oxford University Press, Oxford 2005) 184 et seq.

${ }^{49}$ Judgment of the Supreme Administrative Court of the Czech Republic of 27 September 2005, case 1 Ao 1/2005-98 (available at http://www.nssoud.cz), which relied on Directive 2002/22/EC of the European Parliament and Council of 7 March 2002 on universal service and users' rights relating to electronic communications networks and services (Universal Service Directive) [2002] OJ L 108/51 in order to determine the regulatory aim of number portability.

${ }^{50}$ Judgment of the District Court in Kladno, Czech Republic, of 19 July 2005, case 16 C 109/2004-42, unpublished, which drew interpretative help from Directive 2000/35/EC of the European Parliament and Council of 29 June 2000 on combating late payment in commercial transactions [2000] OJ L 200/35.

${ }^{51}$ Judgment of the Municipal Court in Prague (Civil Division) of 4 January 2005, case 8 CA 6/2004-24, unpublished. The issue was whether or not financial leasing is to be regarded as a type of consumer credit falling within the scope of Council Directive 87/102/EEC of 22 December 1986 for the approximation of laws, regulations and administrative provisions of Member States concerning consumer credit [1987]OJ L 42/48.

52 Judgment of the Supreme Administrative Court of 17 January 2006, case 6 As 52/2004 - 67, n.y.p., where the court relied on Commission Directive 80/723/EEC of 25 June 1980 on the transparency of financial relations between Member States and public undertakings
} 
This sort of interpretive aid need not be limited to issues arising after a new Member State's accession to the European Union. The Polish Constitutional Tribunal, ${ }^{53}$ the Czech Constitutional Court, ${ }^{54}$ the Czech High Court in Olomouc ${ }^{55}$ and the Czech Supreme Administrative Court ${ }^{56}$ have all, on several occasions already, observed that EU law may also serve as an interpretive guide in cases based on pre-accession facts and legal norms.

A recent decision by the Czech Supreme Administrative Court is instructive in this respect. The case arose from a rather technical value-added tax dispute. The complainant, an undertaking taxable under Czech law, reconstructed a glass-welding unit on a property located in Slovakia. The reconstruction contract between the complainant and the Slovak property owner was concluded at the incentive of a third party, a Czech undertaking, which acted as the property owner's agent. The complainant later claimed deduction of value-added tax (VAT) from the fee paid to the agent before the Czech authorities, as both parties to the agency agreement were Czech. The Czech Revenue Authority, however, refused to deduct VAT from the agency contract, claiming that the place of the taxable transaction was Slovakia, where the property was located.

The Supreme Administrative Court observed that the issue in question had not been provided for in the Czech Value-Added Tax Act of 1992, which was in force at the time of the dispute. However, the court went on to state that the Czech Republic's VAT system, introduced at the beginning of the Nineties, had been modelled on examples from the EC. The rules of conflict for determining the place of the taxable transaction under the Czech VAT system were designed similarly to EC ones. A comparison of the relevant provisions of the Czech VAT Act and the Sixth Council

[1980] OJ L 195/35, and the Court of Justice's case law interpreting the notion of a "public undertaking".

${ }^{53}$ Cf. e.g. the decision of 29 September 1997, case K 15/976, published in the Constitutional Tribunal Reports (Orzecznictwo Trybunału Konstytucyjnego. Zbiór Urzędowy, abbreviated as OTK ZU), 3-4/1997, no. 37; the decision of 28 March 2000, case K 27/997, OTK ZU 2/2000, no. 62; the decision of 24 October 2000, case K 12/008, OTK ZU 7/2000, no. 255; the decision of 21 April 2004, case K 33/039, OTK ZU 4A/2004, no. 31; the decision of 31 May 2004, case K 15/0410, OTK ZU 5A/2004, no. 47; the decision of 12 January 2005, case K 24/0412, OTK ZU 1A/2005, no. 3; or the decision of 26 January 2005, case P 10/0413, OTK ZU 1A/2005, no. 7.

${ }^{54}$ Cf. the decision of 29 May 1997, case III. ÚS 31/97 (the "Škoda Auto" case), published in the Constitutional Court Reports (Sbírka nálezů a usnesení Ústavního soudu), Vol. 8, no. 66, p. 149; the decision of 16 October 2001, case Pl. US 5/01 (the "Milk Quota" case), published as 410/2001 Coll.; or the decision of 6 March 2002, case Pl. ÚS 11/01 (the "Czech Railway Act" case), published as 144/2002 Coll.

55 Decision of the High Court in Olomouc of 14 November 1996, published in Právní rozhledy (Legal Horizons) C.H. Beck, Prague, (1997) no. 9, p. 484.

${ }^{56}$ Cf. the judgment of the Supreme Administrative Court of 29 September 2005, case 2 Afs 92/2005-43, available at http://www.nssoud.cz. 
Directive $77 / 388 /$ EEC on harmonisation of VAT was, therefore, appropriate, also taking into account the fact that the European Association Agreement had already required the approximation of certain areas of Czech law - including indirect taxation - to EC standards. The Supreme Administrative Court therefore affirmed the possibility of using EC law as an instrument for interpreting approximated Czech legislation, and applied the Sixth Directive and the Court of Justice's case law.

The indirect use of EC law as a tool for interpreting Czech approximated legislation, even when the latter was adopted prior to the Czech Republic's accession to the EU, is not a new concept. The possibility of such indirect interpretive use had already been upheld by the Czech Constitutional Court in its pre-accession case law. The Constitutional Court's approach was based not on the approximation of technical rules, but rather on common European principles and values:

[...] The Constitutional Court [...] does not share the claimants' opinion that Community law is irrelevant to the Constitutional Court of the Czech Republic, i.e. a state outside the European Union, when assessing constitutionality. Such a statement is unduly simplistic and schematic. One of the sources of primary Community law are the common principles of law which the Court of Justice derives from the constitutional traditions of the Member States of the European Union. [...] The Constitutional Court of the Czech Republic has repeatedly applied these common principles of law, which are not expressly set forth as written legal rules, but are applied in European legal culture (e.g. the principle of proportionality). [...] Primary Community law is thus not foreign to the Constitutional Court; rather, to a great extent - especially in the form of common European principles of law - it permeates the Court's decisional practice. ${ }^{57}$

\section{Problem Areas}

After this rather mosaic-like overview of cases, let us focus on three selected issues in greater detail. They represent areas where the application of EC law in the new Member States is facing considerable challenges.

\section{II.1. Time and temporality}

Unless otherwise provided for in transitional arrangements, European law becomes fully and immediately applicable in all new Member

\footnotetext{
${ }^{57}$ Decision of the Constitutional Court of 16 October 2001, case Pl. ÚS 5/01 (the "Milk Quota" case), published as 410/2001 Sb., p 8902.
} 
States as of their date of accession. ${ }^{58}$ Its effects are to be prospective, i.e. it should apply to new facts and situations. Existing situations and legal relationships that have not fully exhausted their legal effects are indirectly modified with respect to the content of existing rights and obligations. The deliberations of national courts should be made in light of the following principles:

(1) Priority shall be given to express transitional solutions.

(2) In the absence of these, there is the presumptive rule against retroactivity: the substantive rules of Community law must be interpreted as applicable to situations established before their entry into force only insofar as it clearly follows from their terms, objectives or general scheme that such an effect must be recognised.

(3) New rules apply immediately to the future effects of an existing situation which arose under the old rules (principle of immediate effect). A situation is considered existing (pending, current), and therefore covered by immediately applicable rules, if it has not exhausted its legal effects prior to the entry into force of new legislation, but rather continues to produce them as of that date.

(4) Legitimate expectations must be protected. These may form an exception to the application of the principle of immediate effect. ${ }^{59}$

Unfortunately, real life does not follow such clear-cut patterns, and much uncertainty remains in resolving inter-temporal issues. Most of the current EC law cases in the new Member States also involve questions concerning post-accession temporal application of EC law. One example of this type of dispute is a case pending before the High Court in Prague. ${ }^{60}$ It concerns the application of Council Regulation (EC) no. 1346/2000 of 29 May 2000 on insolvency proceedings. ${ }^{61}$ The Regulation provides for main insolvency proceedings to be initiated in the Member State which constitutes the centre of the debtor's main interests. No additional insolvency proceedings should be opened in any other Member State. However, this new regime has applied only since accession. Before accession,

\footnotetext{
${ }^{58}$ Cf. art 2 of the Act Concerning the Conditions of Accession of the Czech Republic, the Republic of Estonia, the Republic of Cyprus, the Republic of Latvia, the Republic of Lithuania, the Republic of Hungary, the Republic of Malta, the Republic of Poland, the Republic of Slovenia and the Slovak Republic and Adjustments to the Treaties on Which the European Union Is Founded, [2003] OJ C 227 E. Cf. case C-122/96 Stephen Austin Saldanha and MTS Securities Corporation v. Hiross Holding AG [1997] ECR I-5325 para 14, or case 258/81 Metallurgiki Halyps A.E. $v$ Commission of the European Communities [1982] ECR 4261 para 8.

${ }^{59}$ In: SL Kaleda, 'Immediate Effect of Community Law in the New Member States: Is There a Place for a Consistent Doctrine?' (2004) European Law Journal, Vol. 10, no. 1, 102-122, 108.

${ }^{60}$ Case no. 12 Cmo 257/2005.

${ }^{61}$ [2000] OJ L 160/1.
} 
Czech courts did not recognise insolvency proceedings in foreign countries, and the assets of an insolvent company on Czech territory were wound up independently of any other proceedings pending abroad.

Deciding this issue under the old procedure, the Municipal Court in Prague, as the court of first instance, opened insolvency proceedings against an Austrian company in April 2004, irrespective of the fact that insolvency proceedings had already begun in Vienna. At the time when this conclusion was reached by the court of first instance, such a decision was perfectly legal. If the line of analysis outlined above is to apply, can the insolvency of a company be called an existing and lasting situation? Since the assets of the company have not yet been wound up, it might be argued that the new rules should now be applicable to them; the appeals court should stay the proceedings and wait for the Austrian court to decide the issue. However, in order to do so, the High Court would have to quash the decision of the Municipal Court opening insolvency proceedings in the Czech Republic in April 2004. The question that arises is on what grounds the High Court could do so. The earlier decision by the Municipal Court was in accordance with the legal situation prior to accession, and the appellate court is bound by the legal situation prevailing at the time when the original decision was made.

It may be argued that in case C-302/04, Ynos, as discussed above, the Court of Justice missed a chance to clarify at least some temporality issues. The Court declined to reply to the question raised by the Hungarian judge, with the following reasoning (para. 35 - 37):

It must, however, be pointed out that the order for reference states that the facts in the main proceedings occurred before the Republic of Hungary acceded to the European Union. The Court has jurisdiction to interpret the Directive only as regards its application in a new Member State with effect from the date of that State's accession to the European Union (see, to that effect, case C-321/97, Andersson and Wåkerås-Andersson [1999] ECR I-3551, paragraph 31).

In this case, as the facts of the dispute in the main proceedings occurred prior to the Republic of Hungary's accession to the European Union, the Court does not have jurisdiction to interpret the Directive.

The opinion of the Court is surprisingly unconditional and categorical. It draws a firm line as to where the facts of the dispute lie. Since the case arose from a situation that occurred before Hungary's accession to the European Union, the Court is not competent to decide.

There is no doubt that the Court was correct in refusing to answer this rather dubious request for preliminary ruling from Hungary. However, since the Court decided to render a judgement in the case (and not dispose of it by means of an order, as suggested by the Advocate General), it could have seized this chance to reiterate and consolidate its position 
on the temporal effects of EU law in the new Member States. Such guidance is much needed in the new Member States at present.

Moreover, designating the circumstance that the facts of the case were anterior to Hungary's accession to the EU as the sole determinant of the Court's competence could be misleading. There are situations in which the facts have occurred prior to accession, yet the resulting legal effects are lasting and there is an ongoing legal relationship between the parties. In similar situations, the content of the legal relationship is modified by EU law, which becomes applicable irrespective of when the key events occurred. The determining factor is thus not whether the facts of the case occurred before or after accession, but whether or not there is a lasting, ongoing legal relationship still producing legal effects.

Similar interpretive problems arise in situations where some facts making up the legal relationship in question arose before accession, and some after. Legal relationships are often complex conglomerates of various legal facts that extend and develop over long periods of time. What if some of the facts of the case occurred prior to accession, and some after it? ${ }^{62}$

The facts anterior/posterior to accession analysis also disregards the huge mass of legislation adopted in the new Member States prior to accession with a view to harmonising national law with Community rules. ${ }^{63}$ Hundreds of pieces of legislation had de facto already implemented Community legislation (most typically directives) before accession, while accession itself had no impact on their content. The national courts have

\footnotetext{
${ }^{62}$ Case $31 \mathrm{Ca}$ 100/2005, pending before the Regional Court in Hradec Králové, Czech Republic. The case concerns the reimbursement of customs duties. A Czech importer imported a great quantity of mozzarella cheese from Italy. The contract between the Czech importer and the Italian producer was concluded shortly before Czech accession to the EU. The cheese was then imported into the Czech Republic, and the customs duty paid. After the date of accession, the importer discovered that the cheese was mouldy, and rescinded the contract. The question arising was whether or not Community law is applicable to this kind of situation; what are the legal facts of the case? The contract was concluded and executed prior to accession, while the rescission and liability issues arose from facts posterior to accession. Similar questions arise with regard to longstanding legal relationships, where new facts emerge over a longer period of time, and the relationship itself may last for decades (pension schemes, employment contracts and the like).

${ }^{63}$ The Ynos case is one of these (n 8): the piece of legislation in question was Council Directive 93/13/EEC on unfair terms in consumer contracts ([1993] OJ L95/29). By virtue of art 67 and 68 of the Association Agreement between the Republic of Hungary and the European Communities and its Member States ([1993] OJ L 347/2), Hungary had been obliged to harmonise its legislation before accession to the EU, including the area of consumer protection. Hungary honoured this obligation by amending its Civil Code in 1994, thus de facto implementing the Unfair Terms in Consumer Contracts Directive. Virtually the same situation existed in the Czech Republic, where implementation of the Directive was carried out prior to accession by means of an amendment to the Civil Code.
} 
already recognised this fact, ${ }^{64}$ and have used Community legislation as an interpretive aid in cases prior to accession, as well as in cases decided after accession but with facts existing prior thereto.

It may be argued that a smooth, gradual approach to the temporal effects of EC law, as adopted by some national courts, is preferable to the abrupt, all-or-nothing division which could be inferred from the Ynos case. There is no doubt that the Court's position will have to be more finely tuned in future case law. ${ }^{65}$

It is certainly true, on the other hand, that Ynos pertains solely to the Court of Justice's competence. Nothing precludes national courts from using Community legislation as an interpretive aid in cases with facts anterior to accession, as they have been doing for the last few years. Nonetheless, the Ynos ruling might have a certain cooling-off effect on national judges in terms of applying Community law. ${ }^{66}$ First, not all judges will be able to make this fine distinction and recognise that Ynos was about the Court of Justice's competence to answer preliminary ruling requests from the new Member States, and not primarily about how national courts are to apply Community law following accession. Second, the Ynos decision might also be used as a basis for deliberately deferring full application of Community law in cases where not all the facts of the case are posterior to accession.

\section{II.2. The legal force of Babel}

An even more intriguing problem regarding full application of Community law in the new Member States stems from the fact that translation and publication of Community legislation is delayed or even completely lacking. Art. 2 of the Act of Accession provides that "[f]rom the date of accession, the provisions of the original Treaties and the acts adopted by the institutions and the European Central Bank before accession shall be binding on the new Member States and shall apply in those States under the conditions laid down in those Treaties and in this Act."

According to Art. 58 of the Act, "[t]he texts of the acts of the institutions, and of the European Central Bank, adopted before accession and drawn up by the Council, the Commission or the European Central

\footnotetext{
${ }^{64}$ See the cases discussed supra, section I.2.3.

${ }^{65}$ It will also have to be clarified with respect to the Court's previous case law, such as case C-302/97 Klaus Konle v Republik Österreich [1999] ECR I-3099, where the Court saw no problem in answering preliminary ruling requests whose facts arose prior to Austria's accession to the European Union.

${ }^{66}$ Especially if the Court of Justice maintains its tough stance of declaring all preliminary ruling requests from new Member States inadmissible because the facts of the case lie anterior to accession; $\mathrm{cf}$. the reasoned order of the Court of 9 February 2006 in case C-261/05 Lakép e.a. (n 4)
} 
Bank in the Czech, Estonian, Hungarian, Latvian, Lithuanian, Maltese, Polish, Slovak and Slovenian languages shall, from the date of accession, be authentic under the same conditions as the texts drawn up in the present eleven languages. They shall be published in the Official Journal of the European Union if the texts in the present languages were so published."

Read conjointly, both articles oblige the institutions which have issued these acts to publish their official translations in the official languages of the new Member States in the Official Journal of the European Union. These translated acts of the institutions were to be published as a Special Edition of the Official Journal. What, however, is the exact moment at which such translated legislation becomes binding and enforceable visà-vis the individual? Is it the moment of accession, or the moment when it is actually published in the language of the respective Member State?

This question is not merely academic. Due to the considerable workload and amount of legislation, publication of the Special Edition was delayed. The printed volumes of the Official Journal, which are the only binding source of EC legislation, were "displayed" 67 only after accession took place. Of the total of 230 volumes planned for publication, only 171 had been published as of 28 November 2005. ${ }^{68}$ This means that not all the legislation which entered into force on the day of accession, and which is being enforced by institutions of the Member States and the Community, has been duly published yet.

The type of disputes that result are well illustrated by a case pending before the Regional Court in Ostrava (Administrative Division), Czech Republic. ${ }^{69}$ The applicant is an importer of red wine who, on 30 September 2004, was fined by the Czech customs authority for incorrect customs declarations during the period from 11 March 2004 to 20 May 2004. Before 1 May 2004, the basis for imposing a fine was the Czech Customs Code; following accession, the legal basis for a fine was the Community Common Customs Tariff, or Commission Regulation (EEC) No 2454/93 of 2 July 1993, which sets forth provisions for implementation of Council Regulation (EEC) No 2913/92 establishing the Community Customs Code. ${ }^{70}$

\footnotetext{
${ }^{67}$ I.e. officially published; the moment of display of a given issue of the Official Journal in the Office for Official Publications is deemed to be the moment of its publication. See case 98/78 A.Racke $v$ Hauptzollamt Mainz [1979] ECR 69 para 17.

68 Information provided, with respect to the Czech Special Edition, by Mr. TL Cranfield, Director-General of the Office for Official Publications of the European Communities, in a letter dated 28 November 2005.

${ }^{69}$ Case 22 Ca 69/2005. The Ostrava Regional Court has stayed the proceedings and submitted a request for preliminary ruling on this very issue by order no. $22 \mathrm{Ca} 69 / 2005-43$ of 10 February 2006.

70 [1993] OJ L 253/1.
} 
The applicant challenged the fine before the administrative court, inter alia on the grounds that the fine was imposed on the basis of a Community regulation which had not been translated and published in the Czech language at the time the act was committed. The statement of facts made by the applicant is correct: the Common Customs Tariff, together with the Commission Regulation, was not published in the Czech Special Edition of the Official Journal until August 2004.

The respondent, i.e. the customs authority, rejected the applicant's argument as abusive. In its point of view, the whole of Community law became binding on all individuals at the very moment of accession, irrespective of whether or not it had been published in Czech. The respondent further argued that a provisional Czech translation was available on the Ministry of Finance's website, so that the applicant could have had access to it there.

This case demonstrates two problems. The first is delayed publication of the legislation in question, and the legislative chaos caused by accession. The second problem is the broader issue of the discrepancy between formal and material sources of law.

Starting with the latter issue, the gap between formal and actual sources of law is obvious. Modern legal systems are based on the concept of the exclusivity of published (printed) sources of law. The "rules of recognition" suggest a given form of publishing and promulgating legal rules. The Community rule of recognition is Council Regulation no. 1, which defines the languages to be used by the European Economic Community, together with Art. 254 ECT. ${ }^{71}$ This regulation provides for the publication of all acts of Community institutions in the respective language version of the Official Journal. Due publication is a precondition for the legal validity of an act. ${ }^{72}$ Furthermore, the act must be published in a language that the addressee is able to understand, i.e. the official language of the Member State in question. ${ }^{73}$

It seems, however, that these "rules of recognition" are somewhat outdated. The vast majority of Community law users have almost never seen a printed version of the Official Journal. Various electronic legal databases have become the genuine sources of law, and the closest one gets to the Official Journal is by downloading an electronic "pdf" version

${ }^{71}$ [1958] OJ 17/385, English Special Edition: Series I, chapter 1952-1958, 59.

72 Cf. case T-115/94 Opel Austria GmbH v Council of the European Union [1997] ECR II-39 paras 127-135; generally, see case 98/78 Racke (n 67).

${ }^{73}$ See case 160/84 Oryzomyli Kavallas OEE and others $v$ Commission of the European Communities [1986] ECR 1633, body 11 - 21; case C-108/01Consorzio del Prosciutto di Parma and Salumificio S. Rita SpA v Asda Stores Ltd and Hygrade Foods Ltd.[2003] ECR I-5121 para 89; and case C-209/96 United Kingdom of Great Britain and Northern Ireland $v$ Commission of the European Communities [1998] ECR I-5655 para 35. 
of it from the EUR-Lex website. The key question at this stage is whether or not the exclusivity of printed sources of law is to be maintained. Once we accept that the source of Community law need not necessarily be the printed version of the Official Journal, ${ }^{74}$ the clear wording of the statutory provisions notwithstanding, what remains is the question of language. The publication of an act in the language of the Member State in question (as far as legislative acts are concerned), or in the language of the addressee of the act (for administrative or individual acts), is a precondition that is difficult to bypass.

There is no doubt that the Court of Justice will, sooner or later, be faced with similar questions. The same set of problems is evident in all the Member States: ${ }^{75}$ translations of Community legislation are delayed or non-existent, and there were no official (and single-version) translations of Community legislation available either shortly before or, especially, immediately after accession. What resulted was a great deal of chaos, in which, for instance, state authorities enforcing basic Community laws (such as the Common Customs Tariff, in the present case) made use of unofficial translations (ideally, in just one version) of Community law, or worked with the English or German versions.

It is quite surprising that there have not been many more cases of this sort up till now. ${ }^{76}$ This may be explained in two ways. First, these cases are still forthcoming. Second, to simply confirm the assumption made at the outset, the formal sources of law no longer correspond with the material ones, and no one seems to have noticed the absence of printed versions of the Official Journal.

How should the Court of Justice approach cases of this type? As mentioned above, two questions will have to addressed: the question of the printed version of the Official Journal and its availability, and the question of language. There are two extreme approaches. The Court could stick to the formal requirements and the formal "rules of recognition", holding that all decision adopted on the basis of legislation not duly

${ }_{74}$ The forerunner to a re-assessment of the official publication of law in Central Europe is Austria, which, as of 2004, abolished the printed version of its Official Gazette (Bundesgesetzblatt). The printed Gazette has been replaced by electronically signed versions in Adobe Acrobat's PDF format, all published at a central address (http://www.ris.bka.gv.at). For more, see Kundmachungsreformgesetz 2004, BGBl. I Nr. 100/2003, 1471.

${ }^{75}$ With the exception of Malta, where the English version of the Official Journal is (temporally) accepted, and Cyprus, where the same task is performed by the Greek edition. As for the remaining eight new Member States, each of them brought their own language into the Community.

${ }^{76}$ With the notable exception of Poland - cf. the order of the Wojewódzki Sad Administracyjny in Bydgozsczy of $20^{\text {th }}$ July 2005, case no. I SA/Bd 275/05, with a case note: A Wróbel, 'Glosa do wyroku Wojewódzkiego Sądu Administracyjnego w Bydgoszczy z 20.07.2005 r. (SA/Bd 275/05), wyrok niepublikowany’ (2006) Europejski Przeglad Sadowy styczen 48 $-53$. 
published in the language of the Member State and in the printed version of the Official Journal are void. ${ }^{77}$ Alternatively, the Court could go the route it suggested in the Oryzomyli Kavallas case, i.e. examining, in each individual case, the actual availability of Community legislation to the individual in question. The question posed in such an inquiry would be whether or not the legislation was absolutely inaccessible, or whether, if the individual had made reasonable effort, he or she could have obtained it.

Both these approaches are highly problematic. If the first route were to be taken, absolute legal chaos would ensue. As mentioned previously, even now all of the volumes of the Special Edition of the Official Journal have still not been issued. These volumes have been published in a quite haphazard manner over the last two years. If legislation could be enforced only after its official printed publication in the Official Journal and in the language of the respective Member State, hundreds or thousands of administrative decisions, contracts and other legal acts adopted on the basis of unofficial translations or other language versions could be void.

The other route is likewise problematic: modern legal systems are based on the notions of equality, territoriality of law, and the legal principle of ignorantia legis neminem excusat. Similar formal approaches have their flaws; they are, however, reliable in that they enable one to ascertain, at any given moment, what the law is. If enforcement of legal rules were to be made subject to the addressee's capacity to read or understand them, the system would revert to the medieval conception of the personality of the law and particular legal regimes, an outcome that is scarcely conceivable.

It is obvious that the Court of Justice cannot reasonably adopt either of these extreme positions. It will have to carefully steer between Scylla and Charybdis in an effort to find a sensible middle way. Whatever solution it adopts, it should bear in mind that its decision might possibly be challenged before one of the Central European constitutional courts. If the Court of Justice were to adopt an overly "pragmatic" approach, this might provoke negative reactions.

Here again, as with the temporal application of EC law, time is on the Community's side. First, all Community legislation will eventually, slowly but steadily, be published in the new Community languages. Sec-

77 The question is, of course, much more complex. It is conceivable that different answers might be found with regard to different types of Community legislation (regulations, directives, decisions) and different types of legal relations (vertical state against the individual, vertical individual against the state, horizontal). These issues are, unfortunately, far beyond the scope of this article. For a good overview, see R Procházka, 'K publicite prameñov. komunitárneho práva' [On Publication of the Sources of Community Law] (2004) Justičná revue, sv. 56, č. $8-9,856$ et seq. 
ond, only decisions or contracts adopted or concluded in the period between the moment of accession and due publication of the relevant piece of Community legislation may be challenged. Locus standi to challenge these acts before courts is limited; moreover, these claims will soon become time-barred.

\section{II.3. Iura novit curia (Does it really?)}

"The court knows the law" - this old Roman maxim has become one of the building blocks of modern continental legal codifications. It means that a judge is obliged to apply valid laws ex officio, i.e. of his or her own motion. The correlative privilege of the parties to the dispute is not to have to argue points of law. This system represents the old idealistic continental model of the mechanical judge: the parties argue the facts, the judge adds the law, and the result is a perfect, syllogistic judgment.

This maxim still dominates the Czech legal system and legal theory. Sections 120 and 121 of the Czech Code of Civil Procedure ${ }^{78}$ define the burden of proof in civil proceedings. The parties are generally obliged to prove their statements, with the exception of all "legal regulations published in the [Official] Collection of Laws". The Czech Code of Administrative Justice, which is a more modern codification, departs somewhat from this maxim by imposing on the parties the burden of submitting to the court not only the facts of the case, but also points of law. ${ }^{79}$

These provisions deeply affect the standard of legal services and quality of applications submitted by advocates to the courts. A typical Czech application is a summary of the facts, several pages long, with only a timid allusion (if any at all) to the applicable law. Should any reference be made to points of law, it will be limited to statutes. No case law or doctrinal writings tend to be mentioned. This practice stands in sharp contrast to the detailed, elaborate analyses common in the Anglo-American legal tradition, where applications are usually dozens or even hundreds of pages long. The Czech and Central European legal systems are, generally, still trapped in the idealistic vision of an all-knowing judge - a judge-machine to which one supplies the facts, then inserts a coin and waits for a neatly-packaged result at the other end.

This ideology is, however, crumbling on all sides, national as well as European. From the national point of view, it has been gradually eroded over the last decade or so. The legislative frenzy of the past ten years, caused by the approximation of laws and the complete renewal of the legal order, leading to what one justice of the Czech Constitutional Court

\footnotetext{
${ }^{78}$ Act no. 99/1963 Coll., as amended.

${ }^{79}$ Para 71, sec 1, item d) of the Code of Administrative Justice, Act no. 150/2002 Coll, as amended.
} 
called its "decomposition", ${ }^{80}$ cannot leave even the greatest judicial optimist with the conviction that judges still know the law. Such a conviction might, arguably, still be tenable in the case of individual codifications, such as the Criminal Code, which provide the basis for an entire area of law. ${ }^{81}$ Yet it is no longer tenable in those areas of law which have no codes, and where judges are obliged to apply dozens or hundreds of acts and regulations. This is especially true of administrative justice.

Where does this leave the application of EU law in the new Member States? The Court of Justice's case law is not of much help in this respect. When assessing the obligation of national judges to apply EU law ex officio, the Court of Justice actually cross-referred the issue and sent it back to the national level: national courts are not obliged to raise issues concerning a breach of Community law of their own motion, provided that national regulations do not require them to do so with respect to a national law. ${ }^{82}$ If the question were to be returned to the national level, and the principle of equality applied, the conclusion would be that Czech judges are obliged to raise points of EC law on their own motion, and to actively seek and apply relevant EC law.

So much for legal theory. Of the dozens of cases decided or pending before national courts in the Visegrad states, as discussed in this paper, there was only one single case where points of Community law were raised by a national judge of his own motion. ${ }^{83}$ In the rest of the cases, EC law points were discussed (sometimes very reluctantly) only after having been expressly raised by the parties' legal representatives.

It appears that the maxim iura novit curia has become almost untenable with respect not only to Community law, but to national law as well. What might have been a workable procedural solution in the era of

${ }^{80}$ In this context, Justice Holländer was referring to the Czech Code of Civil Procedure, which, within one year, had undergone 18 direct and indirect amendments. P Holländer, Ústavnéprávní argumentace [Constitutional Legal Reasoning] (Linde Publishing, Prague 2003) 11 .

${ }^{81}$ However, even in "codified" areas of law, such as criminal justice or criminal procedure, references are often made "outside" the provisions of the code itself.

82 Cf. joined cases C-430 and 431/93 Jeroen Van Schijndel and Johannes Nicolaas Cornelis van Veen $v$. Stichting Pensioenfonds voor Fysiotherapeuten [1995] ECR I-4705 paras 13 - 15; case C-312/93 Peterbroeck, Van Campenhout \& Cie SCS v. Belgian State [1995] ECR I-4599 paras 12 and 14; or case C-72/95 Aannemersbedrijf P.K. Kraaijeveld BV e.a. v Gedeputeerde Staten van Zuid-Holland [1996] ECR I-5403 paras 58 and 60. For more, see e.g. G Canivet and J-G Huglo, 'L'obligation pour le juge judiciaire national d'appliquer d'office le droit communautaire au regard des arrêts Joroen, Van Schijndel et Peterbroeck' (1996) Europe-Revue Mensuelle, Editions du Juris-Classeur, 6e Année, no. 4, 1-4 and S Prechal, 'Community Law in National Courts: The Lessons from Van Schijndel' (1998) 35 CML Rev. 681.

${ }^{83}$ Case C-290/05 Nádasdi (n 4), where the referring court even relied on joined cases C240/98 and C-244/98 Océano Grupo Editorial SA v Roció Murciano Quintero and Emilio Viñas Feliú [2000] ECR I-1491. 
centuries-old legal codes and legislative and judicial stability is no longer possible, given today's tens of thousands of pages of Community and national legislation and case law. We might confidently predict that, at least in the initial stage of application of Community law in the new Member States, EC law arguments will be raised solely or primarily by the parties' legal representatives. This is no surprise in the old Member States, for most EC law angles in domestic disputes have been discovered and raised by the parties. In the new Member States, however, this will be a novelty as far as the position of the parties and the conduct of proceedings is concerned, since iura novit curia has bred inertia among legal representatives. It remains to be seen how far (and how fast) this novelty will spill over into purely domestic cases, where quality legal representation will no longer be a matter of simply reiterating the facts and leaving the court to determine the law.

The gradual abandonment of this maxim also reflects a deeper change in Central and Eastern European legal and judicial ideology. ${ }^{84}$ The omniscient, omnipotent court that knows the entire law is being replaced by an arbiter who needs the parties to tell it what the law is (or might be). The authoritarian approach to law is being replaced by a more discursive model. The responsibility for resolving a dispute no longer rests solely with the inquisitorial judge, but has partially shifted onto the parties and their representatives.

\section{Some generalisations}

To reply to the question raised by the title of this paper, how can the two years of EC law application in the Visegrad states be assessed? None of the catastrophic predictions have come true. The sky did not fall down following accession day, there were no funerals for defunct national sovereignty, ${ }^{85}$ and national courts were not swamped by a flood of "Eurocases". On the other hand, it cannot be said that EC law is absolutely non-existent in the new Member States. The germs of EC law arguments have begun to sprout here and there, some of them assuming rather interesting forms and blossoms.

\footnotetext{
${ }_{84} \mathrm{Cf} . \mathrm{Z}$ Kühn, Aplikace práva soudcem v. éře středoevropského komunismu a transformace. Analýza príčin postkomunistické práuní krize [Judicial Application of Law in Central Europe in the Communist and Transformation Eras. An Analysis of the Post-Communist Legal Crisis] (CH Beck, Prague 2005).

${ }^{85}$ With the exception of those held by more conservative (virtually right-wing) forces in the new Member States, including, in the Czech Republic, the head of state. Cf. J Přibán, 'European Hopes and National Fears: The Czech Constitutional System, Europe's Legacy, Nationalist "Politics of Identity" and New Tensions' in: W Sadurski, J Ziller and K Zurek (eds), Après Enlargement: Legal and Political Responses in Central and Eastern Europe. (Robert Schuman Centre for Advanced Studies, European University Institute, Firenze 2006) 19 -40 .
} 
It is extremely difficult to assess in what number of cases EC law points have been raised so far. It might be noted that dozens of cases involving certain points of EC law are currently pending in the Czech Republic alone, with more being added every day. The start has been rather slow, a fact that may be easily explained by the speed of the judicial process. In civil and criminal cases, the average duration of judicial proceedings at each instance is about one year. By the end of 2005, the first cases involving interesting points of EC law had begun crystallizing in the courts of appeal. This process is even slower in administrative courts; not because they are slower than general courts, but because cases normally have to pass through two instances of administrative authority before they can be reviewed in administrative justice. Moreover, applicants (and the legal community generally) are only slowly becoming aware of the possibilities that EC law offers them. We may suppose that a considerable amount of cases with an EC law angle go through the judicial system without that angle even being noticed.

\section{III.1. New Member States' judges - not such a disaster?}

When writing about the prospects for applying EC law in Central Europe some two years ago, Zdeněk Kühn was rather sceptical. ${ }^{86}$ In his point of view, Central European judges are trapped in the realms of mechanical jurisprudence and textual positivism. They are unable to apply abstract legal principles, they have a negative attitude towards teleological (purposive) argumentation, and they are incapable of using comparative legal arguments. The only type of reasoning they use and understand is that of legal force. More subtle forms of persuasive authority are disregarded. These observations lead Kühn to conclude that this might make for a serious problem once the new European judges start applying European law.

Kühn's analysis is excellent. In its retrospective part, it depicts and highlights the problems of judicial ideology in Central and Eastern Europe ${ }^{87}$ At the same time, however, his analysis is unduly pessimistic as far as the prospects for applying EC law are concerned, since it is based on several incorrect assumptions. It may be argued that the early experi-

${ }^{86}$ Cf. Z Kühn, 'The Application of European Law in the New Member States: Several (Early) Predictions' (2005) 6 German Law Journal no. 3, 565 et seq; Z Kühn, 'New European Judges: Are They Thinking on the Same Wavelength?' (2004) Special Supplement, Common Law Review Prague 9 et seq and Z Kühn, 'Worlds Apart: Western and Central European Judicial Culture at the Onset of the European Enlargement' (2004) 52 Am.J.Comp.L. 531. Similar remarks have been made, with respect to Croatia, by T Ćapeta, 'Courts, Legal Culture and EU Enlargement' (2005) Croatian Yearbook of European Law and Policy 1, 23 - 53.

${ }^{87}$ This retrospective analysis forms part of a larger work recently published as $Z$ Kühn, Aplikace práva soudcem v éře středoevropského komunismu a transformace. Analýza př́čin postkomunistické právní krize, (n 84). 
ence of Community law in the new Member States is not so desperate and gloomy as he predicts.

The primary reservation regarding Kühn's analysis is the problem of a suitable comparator. The author seems to have been carried away with his ideal "new European judge", that "Hercules of Community law", thereby disregarding the actual reality in new as well as old Member States. Kühn's assumptions and vision of what new European judges should be doing are based (exclusively) on the requirements imposed by the Court of Justice's case law, which are often quite remote from reality. It maybe argued, however, that the correct comparator for evaluating the performance of courts in the new Member States in similar types of cases are not the ideal requirements of the Court of Justice, but the national courts of the old Member States and their day-to-day practice in applying EC law.

There is often a considerable gap between the "Luxembourg" version of Community law and Finnish, Greek, English or Hungarian practical application thereof. Taking the example of state liability cases, students of Community law are taught the Francovich case ${ }^{88}$ or the Factortame saga. ${ }^{89}$ They have recently been told that Member States may also be held responsible for judgments rendered in breach of Community law, ${ }^{90}$ or that liability for breaches of EC competition law can also apply in horizontal types of situations. ${ }^{91}$

What the students are not told, however, is that Mr Francovich never received any damages; ${ }^{92}$ that the English courts were unable, even ten years after the initial judgment by the Court of Justice, to substantiate the damages caused to the Spanish fishermen; ${ }^{93}$ that similar problems with regard to horizontal breaches of Community law are likely to arise in the Crehan case; ${ }^{94}$ and that, finally, if Mr Köbler eventually receives some

\footnotetext{
88 Joined cases C-6/1990 and C-9/1990 Andrea Francovich and Daniela Bonifaci and others $v$ Italian Republic [1991] ECR I-5357.

${ }^{89}$ Case C-213/89 The Queen $v$ Secretary of State for Transport, ex parte Factortame Ltd and others [1990] ECR I-2433; joined cases C-46/93 and C-48/93 Brasserie du Pêcheur SA v. Bundesrepublik Deutschland and The Queen $v$ Secretary of State for Transport ex parte: Factortame Ltd and others (III) [1996] ECR I-1029.

90 Case C-224/01 Gerhard Köbler v Republik Österreich [2003] ECR I-10239.

${ }^{91}$ Case C-453/99 Courage Ltd $v$ Bernard Crehan and Bernard Crehan v Courage Ltd and Others [2001] ECR I-6297.

${ }_{92}$ Because he belonged to a group of employees expressly excluded from the scope of the Directive for protection of employees in the event of an employer's insolvency - cf. case C479/93 Andrea Francovich $v$ Italian Republic [1995] ECR I-3843.

${ }^{93} \mathrm{Cf}$. the latest decision in the Factortame saga in $R$. $v$ Secretary of State for Transport Ex $p$. Factortame Ltd (no.6) [2001] 1 W.L.R. 942 [2001] 1 C.M.L.R. 47 [2001].

${ }^{94} \mathrm{Cf}$. the decision of the English Court of Appeal in Crehan $v$ Inntrepreneur Pub Company $C P C$ [2004] E.C.C. 28, currently pending on appeal before the House of Lords.
} 
damages (a scenario which seems rather doubtful), this will happen no earlier than some 15 years after his litigation began. ${ }^{95}$ Similar question marks hover over virtually every area of the Court of Justice's case law; once a case is sent back to the national level, no one seems to bother about whether or how the Court of Justice's decision is applied in practice. ${ }^{96}$ However, the crucial stage in shaping EC law is precisely at the level of national courts; without proper construction and enforcement at the national level, EC law is non-existent, or, at best, reduced to judicial monologues in Luxembourg.

It is precisely this gap between the "Luxembourg" and individual national versions of Community law that results in the aforementioned lack of a suitable comparator. Measuring the "performance" of new Community judges against the Court of Justice's reality-distant requirements ${ }^{97}$ inevitably leads to fallacious conclusions regarding the quality of their reasoning and argumentation. The suitable comparator for judging the quality of "Euro-reasoning" in the new Member States' courts is thus not the Court of Justice's requirements, but rather the practice of other Member States' courts shortly after their accession. Viewed against this background, it may be argued that the new Community judges are not doing much worse than their counterparts in other Member States.

It is true that this statement is, to a great extent, a mere denial of the opposing one, and not a genuine rebuttal of Kühn's analysis of judicial incompetence in Central Europe. There is only limited empirical evidence as to what is genuinely happening before Central European courts. The qualitative analysis given in this article ${ }^{98}$ of more than 30 judicial proceedings or decisions applying EU law in one form or another may justify

95 Cf. case C-224/01 Köbler (n 90) ; the original litigation in Austrian courts started in 1986, when Mr Köbler made his first request for a length-of-service increment to his pension.

${ }^{96}$ With some rare exceptions, such as MA Jarvis, The Application of EC Law by National Courts: The Free Movement of Goods (Clarendon Press, Oxford 1998).

${ }_{97}$ A fine example is the honest remark made by former Advocate General Jacobs in case C-338/95 Wiener S.I. GmbH v Hauptzollamt Emmerich [1997] ECR I-6518. The case concerned, inter alia, a re-appraisal of the CILFIT criteria (Case 283/81 CILFIT, n 18) and the conditions under which a court of last instance may be relieved of its duty to submit a request for preliminary reference to the Court of Justice. One of these exceptions is the socalled acte clair, i.e. a situation where correct interpretation of Community law is so obvious as to leave no room for doubt. However, before a national court concludes that an interpretation is acte clair, it must take into account other language versions of the text. Concerning this requirement, the AG noted (in para 65 of his opinion) that this amounts to demanding of the national court something which even the Court of Justice does not do.

98 This analysis is indeed rather qualitative, i.e. going into depth with individual cases, and not quantitative, i.e. considering a greater amount of cases. However, as already mentioned, the use of Community law in all Member States, including the old ones, is just the "icing on the cake": the vast majority of cases on the overall docket of national courts are decided without any EC law argument. 
the conclusion that the application of EC law in Central Europe is not as disastrous as predicted.

In abstract terms, the suitable comparator problem is clearly visible in one argument put forward by Tamara Ćapeta. In an otherwise insightful analysis of the judicial mentality in Central and Eastern Europe ${ }^{99}$ she argues that one of the greatest problems for formalistic (Eastern) European judges lies in the application of the principles of EC law. She expressly mentions the principle of effectiveness, or effective judicial protection, as one of the most intriguing concepts for the new Community judges. She is, however, fair enough to admit that disregard for the principle of effectiveness "is quite likely to happen in courts of the existing Member States on a daily basis". ${ }^{100}$

It may be argued that the correct conclusion to be drawn from this statement is not, however, that the new Member States' courts must learn to apply this principle, but rather that there is something wrong with it, since it does not seem to be functioning properly even in the most pro-European and progressive national courts of the old Member States. The explanation may lie in the nature of the principle itself: it is an open-ended, everywhere-leading type of argument, by its nature concerned with the legislative choice of a regulatory technique, and not the proper construction of legal rules. That is why national courts virtually never apply this principle of their own motion. When national courts do decide to use it, this is typically a lower court trying to circumvent higher courts, or a higher court wishing to circumvent the legislature. They then submit the question to the Court of Justice on a preliminary reference for quasi-legislative approval, with a view to acquiring external authority for a solution which would be deemed unacceptable under national law.

Similar problems arise regarding the level of Kühn's analysis. His argument is that, in order to apply EC law correctly, all national judges in the new Member States should embrace a teleological and effet utile kind of reasoning, combined with comparative legal arguments. There is, of course, some truth in this statement: there is a distinct style of EC judicial reasoning. However, we may argue that to require a shift of judicial style at all levels of the judicial hierarchy is unrealistic, and even dangerous.

The underlying hypothesis is that there is a considerable difference between the style of judicial reasoning used in supreme or constitutional courts and that which is common in first instance or lower courts. The theory is that the higher we go in the judicial hierarchy, the more elaborate the reasoning ought to be. The judicial style changes (or should

\footnotetext{
99 Ćapeta (n 86).
}

100 Ibid 45. 
change) as well, from more positivistic, text-oriented legal interpretation at the first instance, to more systematic and contextual reasoning at the supreme level. It is suggested that this difference in judicial style is fully justified by the differing requirements placed on courts at different levels: a first instance judge is called upon to gather facts and decide, in an understandable way, regarding an individual case only. If, on the other hand, the complexity or novelty of a case requires an assessment at the highest instance, the supreme justice should view the case in a broader perspective, seeing beyond the individual case and turning to the interpretation of principles, the use of comparative law, contextual and perhaps teleological interpretation of the law, and so on.

In short, the expectations made of the ideal "Hercules" of EC law are often ones which only higher or supreme courts - and not lower courts - are reasonably able to satisfy. The standard for lower courts usually remains a solid, reasonable textual positivism. This is, in a sense, the standard or level of service an average "judicial consumer" can expect from lower courts. If a person goes to a local court to enforce a contract, an elaborate teleological and comparative analysis of the principles of European contract law would seem to be of little use. To require the transformation of every national judges into a Hercules of EC law, a highflier of teleological interpretation, would be just as unfortunate as if all judges were dull formalists.

\section{III.2. Sweet and sour}

Prediction is very difficult, especially if it is about the future. Mindful of this warning allegedly uttered by Niels Bohr, what generalisations and predictions can we make about the application of EC law in the new Member States? As in every story, there are some positive as well as negative aspects; the sweet is mixed with the sour.

Starting with the positive aspects, there are some characteristics of post-communist law and the judiciary which might enable faster, smoother adaptation to, and application of, Community law than in some older Member States. First, as already mentioned above, post-communist legal systems suffer from great legislative instability. Yet this vice may have a positive side effect, one which we may term the "advantage of the momentum of change". The continual and innumerable amendments to virtually every piece of legislation over the last 15 years have created extremely adaptable judges (in a positive as well as a negative sense), who will be able to cope with EC law much more quickly than their colleagues in established old Member States, who are used to the invariability of legal codes dozens or hundreds of years old. On the other hand, it is proper to admit that this ability to absorb new legal provisions does not say anything about the much-needed deeper reform of judicial methodology 
and the argumentation process. It may be claimed, however, that correct application of Community law's substantive provisions is so tightly intertwined with the methodology of applying it that any "incorrect" methodology will soon be detected in the substance of the decision.

Second, there are also some personnel aspects of the Czech judiciary which might speed up the judicial application of EC law. Visegrad judiciaries are, like their continental counterparts, conceived of as career judiciaries. Older generations of career judges have generally not studied EC law (or any sort of "capitalist" law, for that matter), and tend to be limited as far as foreign languages are concerned. The new generation of judges, appointed during the last ten years, at a time when EC law and languages were being taught in law schools, ${ }^{101}$ have a better starting position in finding EC law arguments. To some extent, these capacities are becoming a decisive factor whereby the new generation of judges may be distinguished from the older one. Younger judges, who presently serve on courts of the first instance, may be more eager to use EC law arguments in order to "escape" the supervision of their older colleagues, who control the appellate and supreme levels of the judiciary. Relying on Community law gives junior judges a very powerful source of external authority, which could be used against their more senior colleagues.

The limits of greater application of EC law in the new Member States is not a question of rejection, revolt, or some sort of intentional positivist ignorance of the teleological depth of Community law. The true limits are language barriers and the unavailability of sources. The question of the enforceability of non-translated and unpublished sources of Community law has been briefly discussed above. This problem is, unfortunately, but a small part of the greater problem of a general inaccessibility of Community law in the languages of new Member States. If we consider the fact that not all enforceable legislation has been translated and duly published yet, then what about other sources of Community law (in a broader sense)? The situation in these areas seems even more desperate: almost two years after accession, not one single decision by the Court of Justice has been published in Czech, ${ }^{102}$ there are no detailed doctrinal writings

\footnotetext{
101 At least nominally, leaving aside the question of quality and the real outcome.

${ }^{102}$ Following accession the Court of Justice's case law was to have been published in a Czech version of the European Court Reports. Not a single volume has yet been published. The only available source in Czech remains the Court of Justice's website, where only provisional translations of cases handled by Community courts after 1 May 2004 are posted. Of these, however, less than half are available in Czech, to say nothing of Advocate General Opinions, where the situation is even more problematic. The most important pre-accession cases, a list of which was compiled by the Court of Justice (i.e. the jurisprudence historique, containing 869 key decisions by the Court), are to be published in the Czech Special Edition of the European Court Reports. Translation of these cases only started a few months ago (in late 2005), and none have been published yet.
} 
or textbooks about the majority of EC laws, ${ }^{103}$ and a quick surf on the Internet shows that the vast majority of secondary sources and various types of soft law are accessible only in English or French. ${ }^{104}$

These are the real obstacles to greater application of EC law in the new Member States. This situation also creates a dangerous bitterness among the smaller new Member States, including various complaints about "second-class" membership. It is obvious that some of the fictions concerning linguistic equality within the European Union and the motto "united in diversity" 105 have become indefensible. ${ }^{106}$ The linguistic requirements which a proper application of Community law imposes on an English or French judge are quite different than those faced by a Hungarian or Portuguese one. The example of a Portuguese judge has been chosen deliberately, for the problem of languages is not unique to this last enlargement. The 2004 enlargement only more sharply and broadly revealed the problems already lurking underneath the Europe of 15. A Europe of 25 (and soon 27) will only become more disintegrated and divergent, with the general linguistic Babel contributing greatly thereto.

Despite these practical problems, I would still propose a rather optimistic outlook on the application of Community law in the new Member States. The majority of these problems will be solved with time; some will need more effort on both sides, the national as well as the European. Change will take time, as in any other new Member State. This gradual change will be visible in the style of judicial dialogue as well. The initial stage of EC law application will surely be a merely passive reception of a new and unknown legal order. ${ }^{107}$ It is, however, only a matter of time

\footnotetext{
103 Including areas of utmost importance in EC substantive law, such as the four freedoms, customs law, social security, and judicial cooperation in civil and criminal matters. There are, of course, general textbooks on EC or EU law, yet their generality sets a clear limit on their use by legal practitioners, who are mostly interested in more detailed knowledge or particular information from a specific area of law.

${ }^{104}$ Including, for that matter, the websites of the key European institutions and the main portal http://www.europa.eu.int.

105 Provided, of course, that "diversity" is not a new codename for disintegration. In this respect, the new European motto might compete with the very best of George Orwell ("War is Peace", "Freedom is Slavery", "Ignorance is Power", etc.). Cf. G Orwell, 1984. (Secker and Warburg, London 1949) 2 - 3.

106 Oddly enough, it is the French who normally complain about a disregard for "other" languages within the European Union, despite the fact that French is the last language but one within the EU with any reason to complain - unless, of course, "other" means precisely "French". Cf. e.g. A Fenet, 'Diversité linguistique et construction européenne' (2001) 37 (2) RTD eur. 235 - 269; A Lopes Sabino, 'Les langues dans l’Union européenne - enjeux, pratique et perspectives' (1999) 35 (2) RTD eur. 159 - 169; and B Nabli, 'Les implications de l'élargissement sur le multilinguisme institutionnel de l`Union européenne' (2004) Cahier de droit europeen 40 nos. 1-2, 197 - 223.

107 Ćapeta (n 86) 45.
} 
before the new European judges learn how to use EC law more creatively, and to question some of its principles. ${ }^{108}$

The Community judicial structure should be based on dialogue and mutual intellectual enrichment. There is no doubt that the new Member States' lawyers and judges will have to adjust some of their methodology to European standards. This does not mean, however, that enrichment and "learning" will flow in one direction only, i.e. from the Court of Justice and the "old" Europe to the new Member States. It is not only the vices and ragbags of an outdated post-communist legal conception which the new Member States have brought to the European Union. Some positive values and attitudes may be discovered as well, such as a greater deference to the legislature, or a more "conservative" judicial ideology. Perhaps the time is ripe for the Court of Justice to set its legal reasoning and judicial style on a more solid foundation than the all-embracing, everywhere-leading effet utile can offer.

Central and Eastern European judges generally display a sound degree of scepticism towards the teleological and effet utile style of reasoning used by the Court of Justice. This might be caused by their negative historical experience. Heretical though it may sound, there are some striking similarities between the communist/Marxist and Community approaches to legal reasoning, and the requirements of judicial activism placed on national judges. Marxist law required, at least in its early (Stalinist) phase, that judges disregard the remnants of the old bourgeois legal system in the interest of the victory of the working class and the communist revolution. Judges were supposed to apply the law in an antiformalistic, almost teleological way, always directing their aim towards the victory of the working class and the dialectic approach. EC law requires national judges to set aside all national law which is incompatible with the full effectiveness of Community law, i.e. with such open-ended principles and aims as the full effectiveness of EC law enforcement, or the unity of EC law across the entire Union. In a way, both approaches are very similar: open-ended clauses take precedence over a textual interpretation of the written law. Often the desired result comes first, with a backward style of reasoning being used to arrive at it. The only visible difference is that the universal "all-use" argument has changed - from the victory of the working class to the full effectiveness of EC law.

108 The examples, discussed above, of the first Polish reference for preliminary ruling (case C-313/05 Brzeziński n 5) and one of those from Hungary (case C-290/05 Nádasdi n 12) show that the new Community judges have already understood how to use Community law to get rid of obnoxious national legislation (e.g. a registration tax on imported second-hand cars), which, at least at the national level, does not correspond with the image of a docile, passive legal formalism. 
This comparison is, of course, exaggerated. Yet there is a grain of truth in it. The scepticism towards a teleological style of reasoning shown by post-communist judiciaries has its historical roots. During the last decades of communist rule in Central Europe, legal formalism and strict textual interpretation of the law become a natural line of defence against the anti-formalistic teleological style of judicial reasoning officially required by Party policy. ${ }^{109}$ After the Velvet Revolution, a slow, timid emancipation of the judiciary began. The newly acquired space for interpretive freedom has, naturally, often been misunderstood or even misused. ${ }^{110}$ It is, nonetheless, jealously guarded against new intruders who may try to conquer it using the same methods, albeit with a different content.

On the whole, there is no doubt that, driven by the selfish commercial interests of the parties and their lawyers, Community law will soon begin to appear more often in the new Member States' courtrooms. This will soon become a tidal wave. Yet not in the pessimistic, catastrophic sense Lord Denning MR might have predicted, ${ }^{111}$ but rather in a more positive one, sweeping away the remaining post-communist leftovers from the Augean stable.

\footnotetext{
109 Cf. Kühn (n 84) 86.
}

110 Most notably, as far as the status of previous judicial decisions is concerned, cf. F Emmert, 'The Independence of Judges - A Concept Often Misunderstood in Central and Eastern Europe' (2002) European Journal of Law Reform, vol. 3, 405.

111 "[...] But when we come to matters with a European element, the Treaty is like an incoming tide. It flows into the estuaries and up the rivers. It cannot be held back [...]." Lord Denning MR in H. P. Bulmer Ltd. and Another v. J. Bollinger S.A. and Others [1974] Ch. 401, 418. 